Inflammation, Vol. 12, No. 6, 1988

\title{
LIPOTEICHOIC ACID-ANTILIPOTEICHOIC ACID COMPLEXES INDUCE SUPEROXIDE GENERATION BY HUMAN NEUTROPHILS ${ }^{1}$
}

\author{
ISAAC GINSBURG,$^{2,3}$ SUZANNE E.G. FLIGIEL, ${ }^{4}$ \\ PETER A. WARD, ${ }^{4}$ and JAMES VARANI ${ }^{4}$ \\ ${ }^{2}$ Department of Oral Biology \\ Hebrew University Hadassah School of Dental Medicine \\ Founded by Alpha Omega Fraternity, Jerusalem, Israel \\ ${ }^{4}$ Department of Pathology \\ The University of Michigan Medical School \\ Ann Arbor, Michigan
}

\begin{abstract}
Human neutrophils (PMNs) which have been incubated with lipoteichoic acid (LTA ) from group A streptococci generated large amounts of superoxide $\left(\mathrm{O}_{2}^{-}\right.$ chemiluminescence and hydrogen peroxide when challenged with anti-LTA antibodies. Cytochalasin $\mathrm{B}$ further enhanced $\mathrm{O}_{2}^{-}$generation. The onset of $\mathrm{O}_{2}^{-}$generation by the LTA-anti-LTA complexes was much faster than that induced by BSA-anti-BSA complexes. LTA-treated PMNs generated much less $\mathrm{O}_{2}^{-}$when challenged with BSA complexes, suggesting that LTA might have blocked, nonspecifically, some of the Fc receptors on PMNs. PMNs treated with LTA-anti-LTA complexes further interacted with bystander nonsensitized PMNs resulting in enhanced $\mathrm{O}_{2}^{-}$generation, suggesting that small numbers of LTA-sensitized PMNs might recruit additional PMNs to participate in the generation of toxic oxygen species. Protelolytic enzyme treatment of PMNs further enhanced the generation of $\mathrm{O}_{2}^{-}$by PMNs treated with LTAanti-LTA. Superoxide generation could also be induced when PMNs and anti-LTA antibodies interacted with target cells (fibroblasts, epithelial cells) pretreated with LTA. This effect was also further enhanced by pretreatment of the target cells with proteases. PMNs incubated with LTA released lysosomal enzymes following treatment with anti-LTA antibodies. The amounts of phosphatase, $\beta$-glucoronidase, $N$ acetylglucosaminidase, mannosidase, and lysozyme release by LTA-anti-LTA complexes were much smaller than those released by antibody or histone-opsonized streptococci, suggesting that opsonized particles are more efficient lysosomal enzyme releasers. However, since the amounts of $\mathrm{O}_{2}^{-}$generated by the LTA complexes equaled those generated by the opsonized particles, it is assumed that the signals for triggering a respiratory burst and lysosomal enzyme secretion might be different.
\end{abstract}

'Supported by a research grant from Dr. S. M. Robbins of Cleveland Ohio, and by grants HL288442, HL-31963 and GM-29507, from the National Institutes of Health, Bethesda, Maryland, and by grant IM- 432 from the American Cancer Society.

${ }^{3}$ Visiting Professor at the Department of Pathology, the University of Michigan. 
Generation of $\mathrm{O}_{2}^{-}$by LTA complexes was strongly inhibited by lipoxygenase inhibitors but not by cyclooxigenase inhibitors. Also phenylbutazone, trifluorperazine, and DASA markedly inhibited $\mathrm{O}_{2}^{-}$generation induced by LTA complexes. These data suggest that bacterial products in the presence of antibody might have important biological effects on phagocytic cells and that these effects may be inimical to the host.

\section{INTRODUCTION}

Lipoteichoic acid (LTA) is an ampiphatic macromolecular substance that is associated with the cell wall and protoplast membrane of Gram-positive bacteria (1-3). LTA is composed of polyglycerophosphate or polyribitol phosphate linked to alanine and to a fatty acid (2). LTA was previously identified as the cell-sensitizing agent present in culture supernates of many Gram-positive microorganisms (4).

While the bulk of LTA is firmly bound the bacterial cells (3), some LTA is always present in culture supernates (4-9). LTA can be released in large quantities following treatment of washed bacteria either with phenol (7-9) or with cationic agents (10). Substantial amounts of LTA can also be released during growth of bacteria in the presence of penicillin (11) or with penicillin and fibronectin (12). LTA derived from all Gram-positive bacteria cross-react immunologically (13). One of the most important characteristics of LTA is its capacity to bind spontaneously, via its lipid moiety, to membranes of mammalian cells $(4-9,14-18)$. LTA has also been shown to mediate the adherence of bacteria to epithelial surfaces, thus facilitating their penetration into tissues (15). The adherence of LTA to red blood cells is markedly enhanced by a variety of proteases (19) and both phospholipids and cholesterol of red blood cell membranes might function as binding sites for LTA (19).

Red blood cells that had been presensitized with LTA undergo very strong agglutination (4-9, 19-21) and lysis $(19,20-23)$ following treatment with antiLTA antibodies plus serum complement (complement-dependent cellular cytotoxicity or passive immune kill). Antibodies to LTA are found in the $\operatorname{IgM}$ and IgG fraction of serum (20). LTA, even in high concentrations, is nontoxic if added to cells in the presence of serum $(19,20)$ but toxicity to target cells has been reported when it was employed in serum-free media (24-26).

LTA is a potent activator of complement $(19,20)$ via both the classical (26) and alternative pathways (27). It releases lysosomal enzymes from macrophages (28), inhibits chemotaxis of neutrophils (29) and phagocytosis (30), modulates the mitogenicity of lymphocytes $(31,32)$ and the immune responses (33), and induces bone resorption (35, 36), arthritis (20), encephalitis (36), and nephropathy (37). LTA also induces antibody-dependent cellular cytotoxicity 
(38), the generation of tumor necrosis factor (39), and inhibition of collagen synthesis by fibroblasts (40).

LTA is also considered to function as the natural regulator of the autolytic wall enzymes of certain Gram-positive bacteria (41-43). Removal of LTA from Gram-positive bacterial by penicillin is thought to mediate the bactericidal effect of $\beta$-lactam antibiotics leading to bacteriolysis $(44,45)$.

Since LTA readily binds to neutrophils and further interacts with anti-LTA antibodies, and since immune complexes are known to activate leukocytes to generate oxygen radicals (46), we studied the role of LTA-anti-LTA complexes, bound to neutrophils, in the generation of superoxide and chemiluminescence, and their role in the release of lysosomal enzymes.

\section{MATERIALS AND METHODS}

Lipoteichoic Acid (LTA). LTA was isolated from group A streptococci (type 3 strain C203S) as described (8). It was further purified according to Fischer et al. (47). We are indebted to Makor Chemicals (Sigma, Israel) for the generous gift of LTA. Lyophilized LTA was dissolved in normal saline and kept at $-20^{\circ} \mathrm{C}$.

Determination of LTA. LTA was assayed quantitatively by a modified passive hemagglutination test (PHG) employing a standard preparation of rabbit anti-LTA immunoglobulin kindly supplied by Makor Chemicals. Human red blood cells (RBC) obtained from healthy blood donors were washed several times in saline. A $1 \%$ RBC suspension in PBS (saline-buffered with $0.05 \mathrm{M}$ phosphate, pH 7.4) was treated for 20 min at $37^{\circ} \mathrm{C}$ with various concentrations of LTA in the absence or presence of papain $(20 \mu \mathrm{g} / \mathrm{ml}$ ) (Sigma Chemical Co., St. Louis, Missouri) and L-cysteine $(10 \mu \mathrm{g} / \mathrm{ml})(19,21)$. The treated cells were washed in PBS and resuspended in the same volume of PBS. Twofold dilutions of a standard anti-LTA globulin were prepared in a final volume of $0.2 \mathrm{ml} \mathrm{PBS}$ employing disposable polyethylene tubes; $50 \mu \mathrm{l}$ of LTA-sensitized RCS were then added and the tubes shaken at $37^{\circ} \mathrm{C}$ for $20 \mathrm{~min}$. The titer of PHG was determined after centrifugation at $2000 \mathrm{rpm}$ for $15 \mathrm{sec}$ in a Clay-Adams serofuge. The titer of PHG was determined as the highest dilution of anti-LTA which still induced passive hemagglutination as described $(19,20)$. Results were expressed as hemagglutination units per milligram of immunoglobulin anti-LTA. The anti-LTA preparation used contained approximately 39,000 units $/ \mathrm{mg}$ protein.

In a modified PHG assay both the sensitization of RBC by LTA and the dilutions of antiLTA globulin were performed in a slightly hypotonic PBS $(0.6 \% \mathrm{NaCl}$ ) (I. Ginsburg and S. Portnoy, unpublished results). Under these conditions much smaller amounts of LTA could be detected by PHG. This approach was taken since it was previously shown (48) that lysis of RBC by streptolysin $\mathrm{S}$ of a group A streptococci was considerably enhanced by slightly hypotonic buffers. Hypotonicity might stretch the RBC membrane and expose more binding sites for LTA.

Human Neutrophils (PMNs). Human neutrophils were obtained by consent from healthy blood donors. PMNs were obtained by centrifugation of heparinized blood in a Ficoll-Hypaque gradient followed by dextran sedimentation (49). Residual RBC were lysed by hypotonic saline. The PMNs were resuspended in Hanks' balanced salt solution (HBSS) buffered with 1 mM HEPES buffer, $\mathrm{pH} 7.4$ (49). In some cases, we suspended the PMNs in HBSS-HEPES containing $10 \mathrm{mM}$ sodium azide.

Target Cells. Mouse skin fibroblasts (strain LTK) and green monkey kidney epithelial cells 
(GBM) provided by the Department of Virology, Medical School, Hebrew University. The cells were cultivated in 50-ml Falcon flasks in RPMI 1640 medium containing $10 \%$ fetal bovine serum. Confluent monolayers were trypsinized, washed in HBSS, resuspended in HBSS, and treated for 15-20 min with LTA (see below).

Generation of Superoxide $\left(\mathrm{O}_{2}^{-}\right)$. PMNs $\left(1-5 \times 10^{6} / \mathrm{ml}\right)$ were first sensitized for $20 \mathrm{~min}$ at $37^{\circ} \mathrm{C}$ with LTA $(1-150 \mu \mathrm{g} / \mathrm{ml})$. The cells were washed in HBSS to remove unbound LTA and further treated for $15 \mathrm{~min}$ at $37^{\circ} \mathrm{C}$ with rabbit anti-LTA globulin $(10-250 \mu \mathrm{g}$ protein/mi) in the presence of $80 \mu \mathrm{M}$ cytochrome $c$ (type III, Sigma) PMNs were also stimulated with an immune complex prepared by mixing $100 \mu \mathrm{l}$ of a rabbit anti-BSA globulin $(975 \mu \mathrm{g} \mathrm{Nitrogen} / \mathrm{ml})$ in $1 \mathrm{ml}$ saline, with $120 \mu \mathrm{g}$ of BSA. The complexes were washed in saline and resuspended in $1 \mathrm{ml}$ saline; 10-15 $\mu \mathrm{l}$ of the preformed complex was used to stimulate PMNs in the presence of cytochrome $c$. In some experiments cytochalasin B (CYB) $(2.5 \mu \mathrm{g} / \mathrm{ml}$, Sigma) was added to the reaction mixtures. The LTA-anti-LTA and the immune complex-treated cells were shaken for $15 \mathrm{~min}$ at $37^{\circ} \mathrm{C}$ in a water bath. The tubes were then centrifuged for $10 \mathrm{~min}$ at $150 \mathrm{~g}$, and the superoxide dismutase (SOD) -inhibitable reduction of cytochrome $c$ was read in a double-beam Unicam SP 1700 spectrophotometer at $550 \mathrm{~nm}(49)$. The amounts of superoxide generated were calculated as described $(49,50)$.

Determination of Hydrogen Peroxide $\left(\mathrm{H}_{2} \mathrm{O}_{2}\right) . \quad \mathrm{H}_{2} \mathrm{O}_{2}$ was determined by the method of Thurman et al. (51). Briefly, to stimulated PMNs in HBSS + azide, $200 \mu \mathrm{l}$ of TCA (30\%) were added. The tubes were centrifuged at $2000 \mathrm{rpm}$ for $5 \mathrm{~min}$. The supernates were transferred to fresh polyethylene tubes and $200 \mu \mathrm{l}$ of $\mathrm{Fe}\left(\mathrm{NH}_{4}\right) \mathrm{SO}_{4} \cdot 12 \mathrm{H}_{2} \mathrm{O}(19 \mathrm{mg} / 5 \mathrm{ml}$ distilled water $)$ were added, followed by $100 \mu \mathrm{l}$ of a $25 \%$ solution of $\mathrm{NaCNS}$. The tubes were vortexed and incubated at room temperature for $5 \mathrm{~min}$ to allow maximal development of the color which was read at $480 \mathrm{~nm}$. A standard $\mathrm{H}_{2} \mathrm{O}_{2}$ assay was run daily. The results were expressed as nanomoles per number of PMNs per $10 \mathrm{~min}$.

Measurement of Chemiluminescence $(C L)$. Luminol-dependent $C L$ was induced in PMNs by LTA-anti-LTA complexes, as described for polycation-opsonized bacteria (52). Briefly, PMNs $\left(1-5 \times 10^{6}\right)$ were pretreated for $15 \mathrm{~min}$ at $37^{\circ} \mathrm{C}$ with various concentrations of LTA. The cells were washed in HBSS-HEPES and various amounts of anti-LTA globulin were added. The tubes were vortexed and immediately transferred to an LKB-Wallac 1250 luminometer which had been equilibrated at $37^{\circ} \mathrm{C}$ by water circulation. CL was monitored on a recorder, as millivolts (49).

Release of Lysosomal Enzymes by Stimulated PMNs. Human PMNs $\left(5 \times 10^{6} / \mathrm{ml}\right)$ were treated for $10 \mathrm{~min}$ at $37^{\circ} \mathrm{C}$ with: (1) LTA $(50 \mu \mathrm{g} / \mathrm{ml})$ followed $15 \mathrm{~min}$ later by washing of the cells with HBSS and further treatment for $20 \mathrm{~min}$ with anti-LTA Ig (300 $\mu \mathrm{g}$ protein/ml); (2) $20 \mu \mathrm{l}$ of group A streptococci preopsonized with anti-LTA antisera which also contained large amounts of agglutinating antibodies to streptococci and with $10 \%$ fresh human serum as a source of complement; and (3) $20 \mu \mathrm{l}$ of streptococci mixed with $100 \mu \mathrm{g} / \mathrm{ml}$ of histone (type II-A, Sigma). All of these agents have been found to induce the generation of large amounts of superoxide, but they did not release lactic dehydrogenase (LDH). Cytochalasin B $(2.5 \mu \mathrm{g} / \mathrm{ml}$ in DMSO) was added to all the tubes. Following incubation, the cells were removed by centrifugation at $800 \mathrm{~g}$ for $10 \mathrm{~min}$, and the supernatant fluids were assayed with lysosomal enzymes (see below).

Assay of Lysosomal Enzymes. Paranitrophenyl derivatives of phosphate $(50 \mu \mathrm{g} / \mathrm{ml})$ of $N$ acetylglucosaminide $(400 \mu \mathrm{g} / \mathrm{ml}), \beta$-glucuronide $(100 \mu \mathrm{g} / \mathrm{ml})$, and mannose $(100 \mu \mathrm{g} / \mathrm{ml})$ (all Sigma products) were added to tubes containing $0.8 \mathrm{ml}$ of $0.1 \mathrm{~N}$ acetate buffer, $\mathrm{pH} 5.0 ; 150 \mu 1$ aliquots of the PMN supernates were added, and the tubes were incubated at $37^{\circ} \mathrm{C}$ for various time intervals (see below). The release of free paranitrophenol was determined at $400 \mathrm{~nm}$ by the addition of 0.5 $\mathrm{ml}$ of $0.1 \mathrm{~N} \mathrm{NaOH}$. Lysozyme was determined by lysis of $M$. lysodeikticus. Supernates from PMNs which had been frozen and thawed five consecutive times were considered to contain $100 \%$ of the total amount of enzymes.

Effect of Drugs on $\mathrm{O}_{2}^{-}$Generation Induced by LTA-Anti-LTA Complexes. The following 
drugs were tested for their capacity to modulate the generation of superoxide following stimulation of PMNs by LTA-anti-LTA complexes: nordihydroguaiaretic acid (NDGA) (a putuative lipoxygenase inhibitor), indomethacin and ibuprofen (putative cyclooxygenase inhibitors), phenylbutazone (an antiinflammatory agent), trifluroperazin (an antagonist of calmodulin), and diazobenzene sulfonic acid (DASA) (an inhibitor of surface membrane proteins (53). All drugs were dissolved in DMSO at $10 \mathrm{mg} / \mathrm{ml}$ and further diluted in HBSS to the appropriate concentration. LTA-sensitized PMNs were preincubated with the various drugs for $10 \mathrm{~min}$ at $37^{\circ} \mathrm{C}$ and then further treated with anti-LTA globulin. The amounts of NDGA which inhibited superoxide generation by the PMNs were below the amounts which reduce cytochrome $c$. Controls containing the appropriate amounts of DMSO were run in parallel. None of the drugs, at the concentrations employed, had any cytotoxic effects on the PMNs as determined by the release of lactic dehydrogenase.

\section{RESULTS}

Generation of $\mathrm{O}_{2}^{-}$by LTA-Anti-LTA Complexes. Figure 1 shows that PMNs which had been pretreated with increasing concentrations of LTA generated progressive amounts of $\mathrm{O}_{2}^{-}$following treatment with anti-LTA globulin. This reaction is specific since nonimmune rabbit globulin failed to induce any superoxide generation. LTA by itself invariably failed to induce any traces of

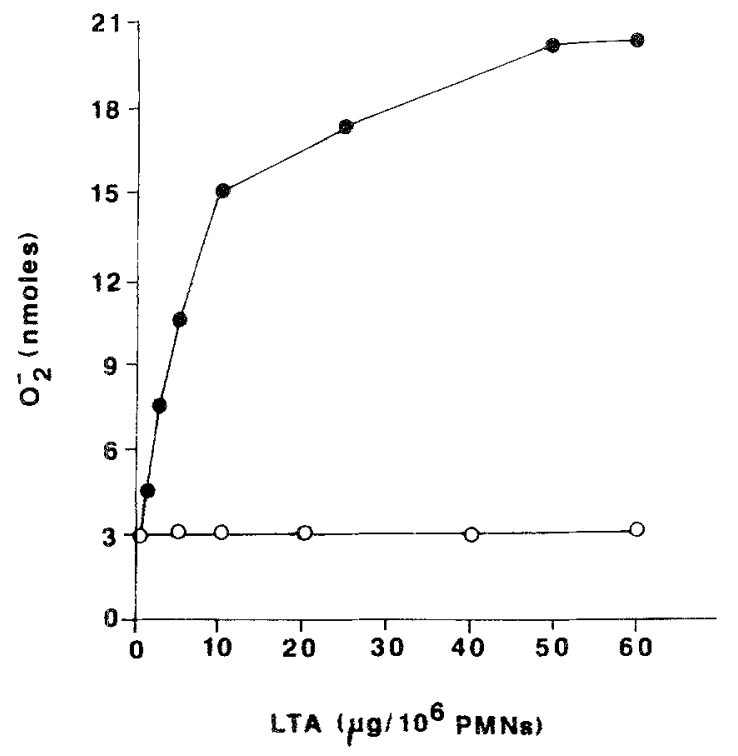

Fig. 1. Generation of $\mathrm{O}_{2}^{-}$by LTA-sensitized PMNs treated with anti-LTA. PMNs $\left(10^{6} / \mathrm{ml}\right)$ were preincubated for $15 \mathrm{~min}$ at $37^{\circ} \mathrm{C}$ with increasing amounts of LTA. The cells were washed, resuspended in HBSS, and exposed to anti-LTA Ig $(250 \mu \mathrm{g}$ protein/ml) ( $\rightarrow$ ) or to nonimmune rabbit $\operatorname{Ig}(250 \mu \mathrm{g} /$ protein $)(0-0)$. 
$\mathrm{O}_{2}^{-}$. Optimal generation of $\mathrm{O}_{2}^{-}$by the LTA-anti-LTA complexes depends on the presence of extracellular calcium and magnesium (not shown). Figure 2 compares the time course of $\mathrm{O}_{2}^{-}$generation induced by LTA-anti-LTA and by $\mathrm{BSA}$-anti-BSA complexes. The reaction mixtures were incubated at $25^{\circ} \mathrm{C}$ to allow a slower rate of $\mathrm{O}_{2}^{-}$generation. This also was done to determine the lag periods of $\mathrm{O}_{2}^{-}$generation. The onset of $\mathrm{O}_{2}^{-}$generation by the LTA complex was much faster and the lag period for $\mathrm{O}_{2}^{-}$generation shorter than that induced by the BSA-anti-BSA complex. While $1.5 \mathrm{~min}$ were needed to induce the generation of half-maximal amounts of $\mathrm{O}_{2}^{-}$by the LTA-anti-LTA complex, about 8 min were needed to achieve half-maximal generation of $\mathrm{O}_{2}^{-}$by the BSA-antiBSA complexes. When assayed at $37^{\circ} \mathrm{C}$ the half-maximal generation of $\mathrm{O}_{2}^{-}$by the LTA-anti-LTA and by the BSA-anti-BSA complexes was 1 and 4 min, respectively. It was not possible to determine with accuracy the lag period of $\mathrm{O}_{2}^{-}$generation induced by LTA-anti-LTA complexes with the method employed.

The rapid onset of $\mathrm{O}_{2}^{-}$generation by the LTA complex might be linked with the intense agglutination of the cells which took place following the addition of anti-LTA antibodies and the capacity of the same LTA-sensitized PMNs

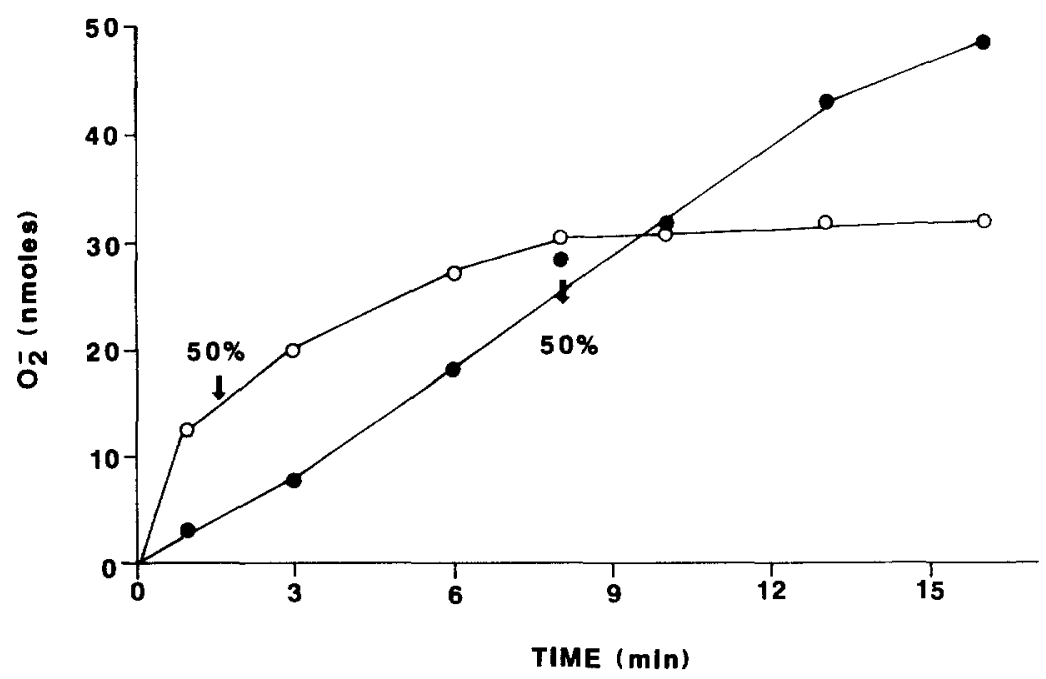

Fig. 2. Time course of $\mathrm{O}_{2}^{-}$generation induced by LTA and by BSA complexes. $3 \times 10^{6}$ PMNs were treated with LTA $(100 \mu \mathrm{g} / \mathrm{ml})$ for $15 \mathrm{~min}$ at $37^{\circ} \mathrm{C}$. The cells were washed, and anti-LTA globulin $(250 \mu \mathrm{g}$ protein $/ \mathrm{ml})$ was added to each of the tubes containing LTA-sensitized PMNs $(\bigcirc-O)$. In parallel, the same number of nonsensitized PMNs were treated with $10 \mu \mathrm{l}$ of BSAanti BSA complexes (see Materials and Methods) ( $\bullet$ ). The reaction mixtures were incubated for various time intervals at $25^{\circ} \mathrm{C}$ in a shaking bath in the presence of CYB $(2.5 \mu \mathrm{g} / \mathrm{ml})$ and cytochrome $c(80 \mu \mathrm{M})$. 
to further interact via the $\mathrm{Fc}$ portion of the immunoglobulin with neighboring PMNs (see below).

As was the case with superoxide generation, chemiluminescence signals were also generated very rapidly (within seconds) following the addition of antiLTA globulin to presensitized PMNs (Figure 3). It was also found that about $50 \%$ inhibition of superoxide generation induced by BSA-anti-BSA complexes took place (Figure 4) when such complexes were added to LTA-presensitized PMNs, suggesting that LTA might have somehow blocked $F c$ receptors on PMNs. Even higher inhibitory effects $(70 \%)$ were noticed when small amounts of BSA-anti-BSA complexes were employed to stimulate the LTA-presensitized PMNs. Despite such inhibition, the total amount of $\mathrm{O}_{2}^{-}$generated when PMNs were simultaneously challenged with LTA-anti-LTA and with BSAanti-BSA complexes was always greater than the amounts induced by each complex alone. These results suggest that "multiple hits" induced by two or more ligands might enhance the oxygen burst in leukocytes (see 53, 56).

The dependence of $\mathrm{O}_{2}^{-}$generation on the amount of anti-LTA globulin and the relationship of $\mathrm{O}_{2}^{-}$production to the agglutination of PMNs is shown in Figure 5. A marked increase in both superoxide generation and cell agglutination occurred proportional to the amount of anti-LTA globulin, suggesting that

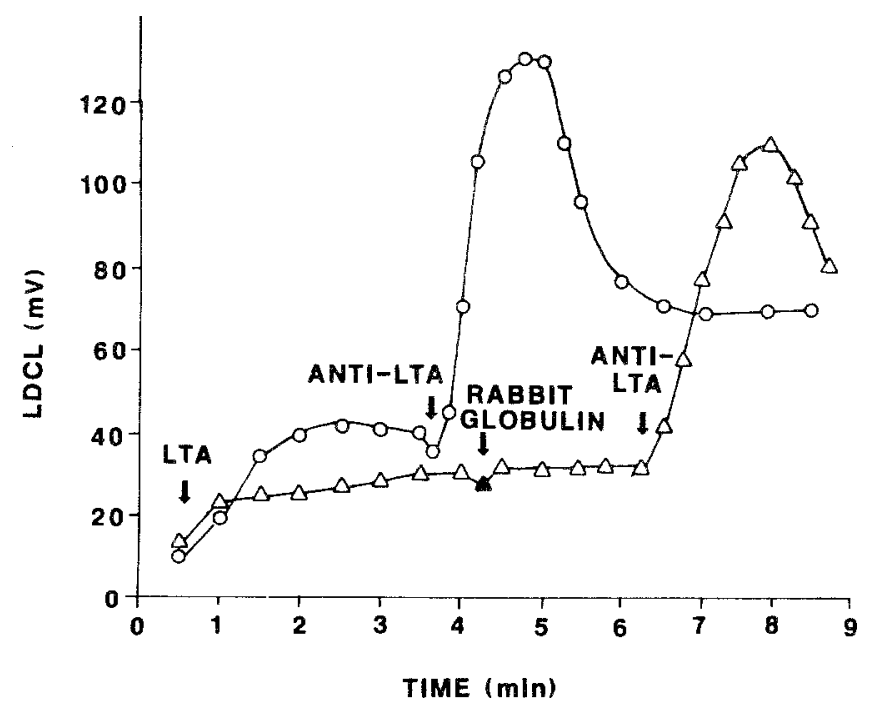

Fig. 3. Luminol-dependent chemiluminescence (LDCL) induced in PMNs by LTA-anti-Lta complexes. PMNs $\left(2.5 \times 10^{6} / \mathrm{ml}\right)$ were preincubated for $15 \mathrm{~min}$ at $37^{\circ} \mathrm{C}$ with $25 \mu \mathrm{g} / \mathrm{ml}$ of LTA. The cells were washed, resuspended in HBSS, and treated (arrow) either with anti-LTA globulin (250 $\mu \mathrm{g}$ protein/ml) or with nonimmune globulin. Note the very fast $\mathrm{CL}$ signals induced by the LTA complex. 


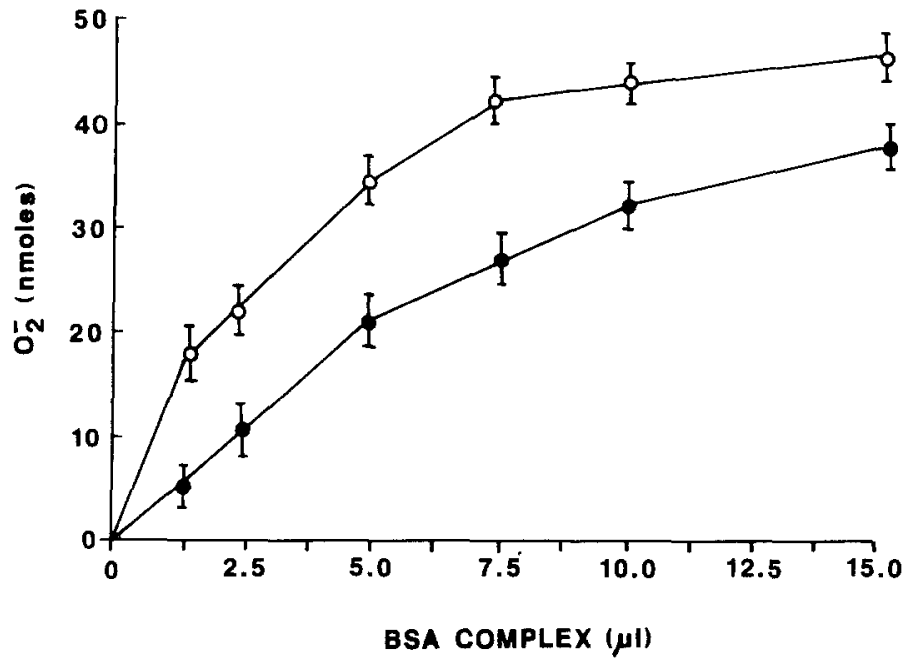

Fig. 4. Superoxide generation by LTA-sensitized PMNs challenged by BSA-anti-BSA complexes. PMNs $\left(30 \times 10^{6} / \mathrm{ml}\right.$ were pretreated for $20 \mathrm{~min}$ at $37^{\circ} \mathrm{C}$ with LTA $(500 \mu \mathrm{g} / \mathrm{ml})$. The cells were washed in HBSS, and an aliquot of $3 \times 10^{6}$ cells was treated with increasing amounts of BSAanti-BSA complex $(\bigcirc-O)$ (see Materials and Methods). In parallel $3 \times 10^{6}$ nonsensitized PMNs were treated by BSA complexes $(\longrightarrow)$. Both CYB $(2.5 \mu \mathrm{g} / \mathrm{ml})$ and cytochrome $c(80 \mu \mathrm{M})$ were added to all tubes, and the reaction mixtures were further incubated for $10 \mathrm{~min}$ at $37^{\circ} \mathrm{C}$. Note that LTA-presensitized PMNs produced less superoxide when challenged by the immune complex. The data are the average and standard deviation of the mean of three experiments performed in duplicate.

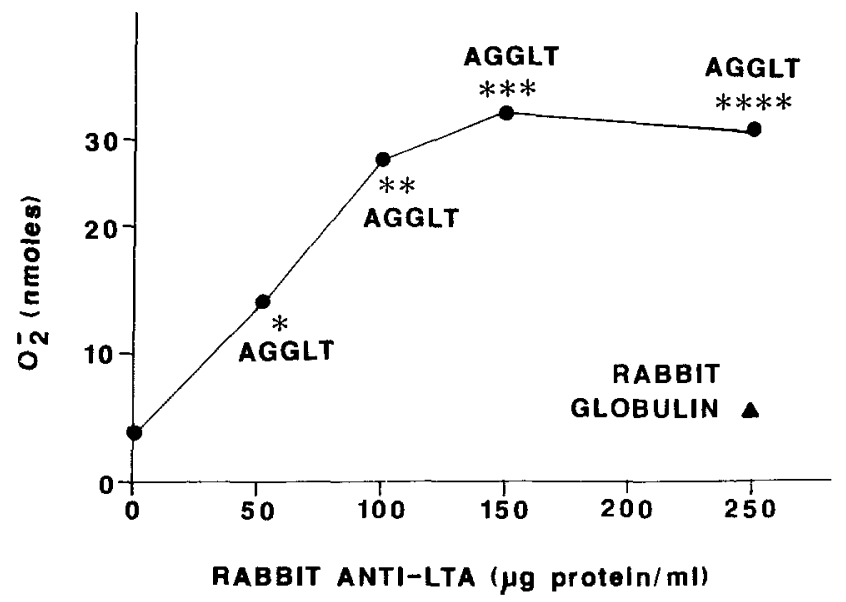

Fig. 5. Effect of anti-LTA concentration on $\mathrm{O}_{2}^{-}$generation by PMNs sensitized by LTA. $3 \times 10^{6}$ PMNs were preincubated for $15 \mathrm{~min}$ at $37^{\circ} \mathrm{C}$ with $50 \mu \mathrm{g} / \mathrm{ml}$ of LTA isolated from Streptococcus pyogenes. The cells were washed with saline, resuspended in HBSS, and treated with increasing amounts of rabbit-anti LTA IgG $(\bullet-)$ ) or with nonimmune rabbit UgG ( $\bullet$ ). AGGLT = degree of PMN agglutination: *, several cells per clump; **, 5-10 cells/clump; ***, 20-50 cells per clump; $* * *$, over 50 cells per clump. 
LTA had been bound to the PMN surfaces prior to its interaction with anti-LTA antibodies. Nonspecific rabbit Ig failed to induce either agglutination or superoxide generation.

The effect of cytochalasin $\mathrm{B}(\mathrm{CYB})$ on $\mathrm{O}_{2}^{-}$generation by LTA-anti-LTA complexes is shown in Figure 6. Much larger amounts of superoxide were generated in the presence of CYB which is similar to the findings with other ligands (49). As expected, LTA-anti-LTA complexes also induced the generation of $\mathrm{H}_{2} \mathrm{O}_{2}$ by PMNs.

Since proteases were found to enhance the binding of LTA to RBC, presumably by unmasking more binding sites (19), we also treated PMNs either with crystalline trypsin $(10 \mu \mathrm{g} / \mathrm{ml})$ or with pronase $(10 \mu \mathrm{g} / \mathrm{ml})$ and tested their capacity to generate $\mathrm{O}_{2}^{-}$following stimulation with LTA-anti-LTA complexes. A $20-30 \%$ enhancement of superoxide generation over controls was invariably observed (data not shown), suggesting that proteases released from activated leukocytes in vivo might also enhance oxygen radical generation by PMNs stimulated by LTA-anti-LTA complexes. Since LTA of all Gram-positive bacteria cross-react immunologically (13) and since normal human serum always contains anti-LTA antibodies, it is likely that sensitization of mammalian cells with LTA is a common occurrence in vivo. Since LTA bound to PMNs interacts with anti-LTA antibodies, the Fc portion of the immunoglobulin might also be

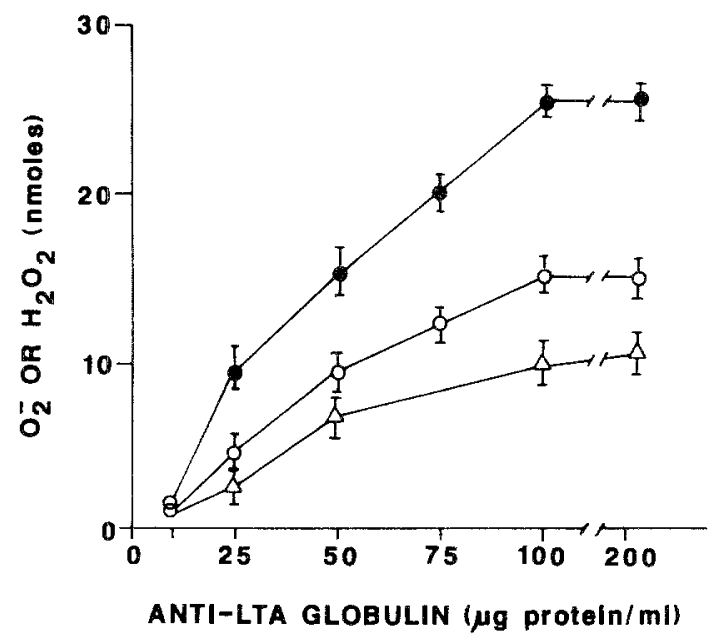

Fig. 6. Generation of oxygen radicals by PMNs treated with LTA-anti-LTA complexes. PMNs $\left(3 \times 10^{6} / \mathrm{ml}\right)$ in HBSS + azide $(10 \mathrm{mM})$ were preincubated for $20 \mathrm{~min}$ at $37^{\circ} \mathrm{C}$ with LTA $(50 \mu \mathrm{g} /$ $\mathrm{ml}$ ). The cells were then washed in HBSS and resuspended in the same buffer and treated with increasing concentrations of anti-LTA-Ig in the absence or presence of CYB $(2.5 \mu \mathrm{g} / \mathrm{ml})$. $\bigcirc$, superoxide; $\bullet$, superoxide generation in the presence of $\mathrm{CYB} ; \triangle \longrightarrow \triangle$, hydrogen peroxide. Note that CYB enchanced $\mathrm{O}_{2}^{-}$generation and that the ratio of $\mathrm{O}_{2}^{-}$to $\mathrm{H}_{2} \mathrm{O}_{2}$ generated by LTA and anti-LTA complexes is about 1.4. 
free to interact with nonsensitized PMNs. This might further increase the amounts of superoxide.

Effect of Bystander PMNs on $\mathrm{O}_{2}^{-}$Generation Induced by LTA-Anti-LTA Complexes. Since PMNs incubated with LTA and then interacted with antiLTA globulin might further interact via the Fc portion of the antibody molecule with nonpretreated bystander PMNs, we measured $\mathrm{O}_{2}^{-}$generation in a mixture of PMNs, some of which had been incubated with LTA and some of which had not been preincubated with LTA. Thirty $\times 10^{6} \mathrm{PMNs}$ were preincubated for $20 \mathrm{~min}$ at $37^{\circ} \mathrm{C}$ with $1 \mathrm{mg} / \mathrm{ml}$ of LTA. The cells were washed with HBSS to remove unbound LTA. Increasing numbers of PMNs $\left(1-5 \times 10^{6} / \mathrm{ml}\right)$ pretreated with LTA were treated with anti-LTA-globulin $(250 \mu \mathrm{g}$ protein $/ \mathrm{ml})$ in the presence of CYB and cytochrome $c$. In parallel, to the same numbers of LTApretreated PMNs were added untreated PMNs so that each tube contained a total of $5 \times 10^{6}$ PMNs (i.e., increasing numbers of sensitized PMNs and decreasing numbers of nonsensitized PMNs). Anti-LTA globulin (20 $\mu \mathrm{g}$ protein $/ \mathrm{ml}$ ) was added to these PMNs mixtures. Figure 7 shows that while neither

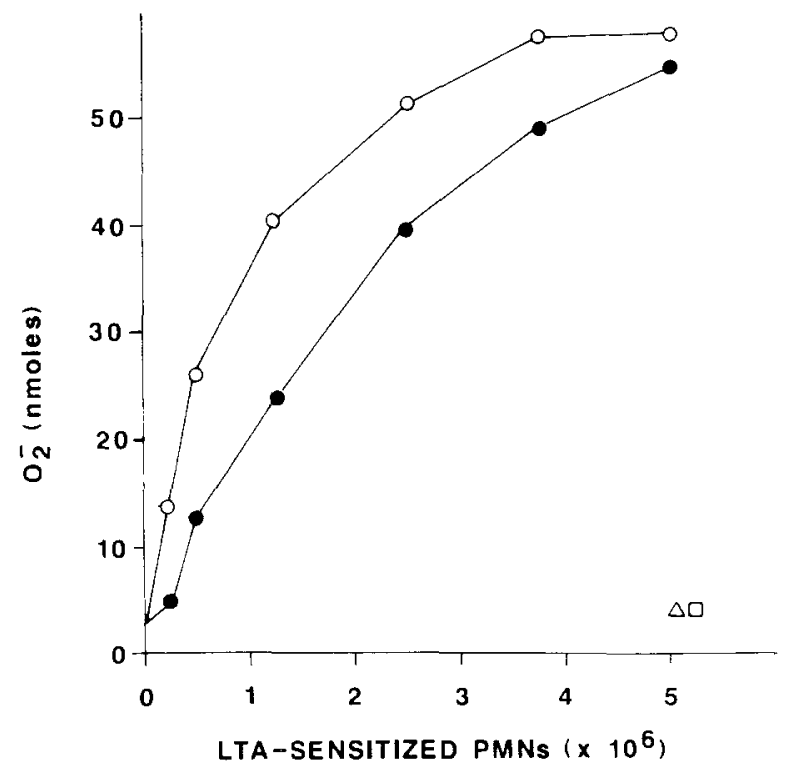

Fig. 7. Effect of bystander PMNs on superoxide generation induced by LTA-anti-LTA complexes. Increasing numbers of PMNs sensitized with $100 \mu \mathrm{g} / \mathrm{ml}$ of LTA were treated with anti-LTA globulin $(250 \mu \mathrm{g}$ protein $/ \mathrm{ml})(\bullet-\bullet)$. To similar increasing numbers of LTA-sensitized PMNs were added decreasing numbers of nonsensitized PMNs ( $-\infty$ ) so that each tube contained a total of $5 \times 10^{6}$ PMNs. CYB and cytochrome $c(80 \mu \mathrm{M})$ werre added to all mixtures. Note the enhancement of $\mathrm{O}_{2}^{-}$generation in the presence of bystander ("nonsensitized") PMNs and that neither PMNs alone $(\square)$ nor LTA-treated PMNs $(\triangle)$ produced $\mathrm{O}_{2}^{-}$. 
PMNs nor LTA-pretreated PMNs in which no anti-LTA had been added had the capacity to generate $\mathrm{O}_{2}^{-}$, a marked enhancement of $\mathrm{O}_{2}^{-}$generation took place when nonsensitized PMNs were mixed with sensitized cells, suggesting that the bystander PMNs interacted, perhaps via the Fc portion of the membrane-bound antibodies, to augement superoxide generation (see Discussion).

Since LTA-anti-LTA complexes activate complement via the classical and alternative pathways $(26,77)$ and also since distinct cytopathic changes were induced in LTA-sensitized target cells which had been treated with complement-sufficient anti-LTA sera $(19,22,23)$, it was also of interest to examine the possibility that complement activation might also enhance superoxide generation. In preliminary experiments performed in collaboration with Dr. G. Till, it was found that the addition of either human or guinea pig serum containing $10-20 \mathrm{CH}_{50}$ units of complement to LTA-sensitized PMNs in the presence of anti-LTA globulin did not result in a significant enhancement of superoxide generation.

Effect of Poly-L-Histidine (PHSTD) on Generation of $\mathrm{O}_{2}^{-}$by PMNS Pretreated with LTA-Anti-LTA Complexes. In all the experiments reported above, the amounts of $\mathrm{O}_{2}^{-}$generated by PMNs $\left(3-5 \times 10^{6} / \mathrm{ml}\right)$ following stimulation by LTA-anti-LTA complexes seldom exceeded $25 \mathrm{nmol} / 10 \mathrm{~min}$. Usually smaller amounts were recorded. Since the number of PMNs usually yielded much more superoxide following stimulation either by phorbol esters or by PHSTD $(49,52)$, it was of interest to establish the capacity of PMNs which had been stimulated by LTA-anti-LTA complexes to produce additional amounts of $\mathrm{O}_{2}^{-}$. This was tested in a system where the PMNs were first stimulated by LTA-anti-LTA and then further stimulated either with poly-L-histidine (49) or with PMA. PHSTD had been shown by us to be one of the most potent stimulators of superoxide generation known $(49,52)$. Table 1 shows that while approximately $50 \mathrm{nmol}$ of $\mathrm{O}_{2}^{-}$are generated by $5 \times 10^{6}$ PMNs stimulated by PHSTD, PMNs pretreated with LTA-anti-LTA complexes yielded approximately $30 \mathrm{nmol}$ of $\mathrm{O}_{2}^{-}$. Protease pretreatment of PMNs prior to the addition of LTA enhanced $\mathrm{O}_{2}^{-}$generation following the addition of anti-LTA. A further substantial enhancement of $\mathrm{O}_{2}^{-}$generation occurred, however, when the LTAanti-LTA-treated cells were treated with PHSTD, suggesting that LTA-antiLTA complexes did not exhaust the $\mathrm{O}_{2}^{-}$-generating capacity of PMNs and that LTA-treated cells might further respond to other ligands with a further generation of $\mathrm{O}_{2}^{-}$. Similar results (data not shown) were obtained with PMA. The only case in which PHSTD failed to further augment $\mathrm{O}_{2}^{-}$generation was the reaction mixture containing anti-LTA Ig (Table 1). Since no such effect was obtained with PMA, it was assumed that serum globulin interfered with the interaction of PHSTD with the PMNs. This assumption was corroborated employing nonspecific rabbit globulin. PHSTD also failed to enhance $\mathrm{O}_{2}^{-}$generation in the presence of CYB in reaction mixtures containing PMNs which 
Table 1. Effect of Poly-L-Histidine (PHSTD) on Generation of $\mathrm{O}_{2}^{-}$by PMNs Stimulated by LTAAnti-LTA Complexes ${ }^{a}$

\begin{tabular}{llrrrr}
\hline & & \multicolumn{3}{c}{$\mathrm{O}_{2}^{-}$generated (nmol) } \\
\cline { 3 - 6 } \multicolumn{1}{c}{ PMNs pretreated with } & Followed by & \multicolumn{2}{c}{$\begin{array}{c}\text { - CYB } \\
\text { +PHSTD }\end{array}$} & $\begin{array}{c}\text { +CYB } \\
\text { + PHSTD }\end{array}$ \\
\hline None & None & 9.6 & 38.8 & 7.4 & 19.4 \\
LTA & Anti-LTA & 30.6 & 39.5 & 48.6 & 48.6 \\
LTA + trypsin & Anti-LTA & 35.2 & 42.7 & 48.3 & 49. \\
LTA + pronase & Anti-LTA & 39.6 & 47.2 & 52.7 & 53. \\
None & Anti-LTA & 10.1 & 17.7 & 8.1 & 18.0 \\
LTA & None & 11.8 & 42.4 & 8.8 & 19.0 \\
LTA + trypsin & None & 11.0 & 39.4 & 7.0 & 8.0 \\
LTA + pronase & None & 8.0 & 41.3 & 8.1 & 12.0 \\
Poly-L-histidine $(150 \mu \mathrm{g} / \mathrm{ml})$ & None & 50.6 & - & 48.0 & - \\
\hline
\end{tabular}

${ }^{a}$ Neutrophils $\left(5 \times 10^{6}\right)$ were pretreated for 20 min at $37^{\circ} \mathrm{C}$ either with HBSS, trypsin $(10 \mu \mathrm{g} / \mathrm{ml})$ or pronase $(10 \mu \mathrm{g} / \mathrm{ml})$ in the presence of LTA $(30 \mu \mathrm{g} / \mathrm{ml})$, or with PHSTD $(150 \mu \mathrm{g} / \mathrm{ml})$. The cells were washed in HBSS, and anti-LTA Ig $(250 \mu \mathrm{g}$ protein $/ \mathrm{ml})$ plus cytochrome $c(80 \mu \mathrm{M})$ were added in the absence or presence of cytochalasin B (CYB) $(2.5 \mu \mathrm{g} / \mathrm{ml})$. The reaction mixtures were agitated and further incubated for $10 \mathrm{~min}$ at $37^{\circ} \mathrm{C}$. The supernates were read at $550 \mathrm{~nm}$, returned to the tubes, which were agitated once more, and PHSTD $(150 \mu \mathrm{g} / \mathrm{ml})$ was added as a stimulus. The tubes were again agitated vigorously and returned to the water bath for 10 additional minutes at $37^{\circ} \mathrm{C}$. The tubes were centrifuged at $2000 \mathrm{rpm}$ and the supernates were again read at $550 \mathrm{~nm}$.

had been pretreated with LTA and with proteases, but which were not further treated with anti-LTA Ig. The reasons for this phenomenon are not understood, however.

Effect of Histone on Superoxide Generation. Previous studies from our laboratory have shown that cationic polyelectrolytes markedly enhance superoxide generation by immune complexes $(49,52,54-56)$. It was, therefore, of interest to examine the effect of histone on superoxide generation induced by LTA-anti-LTA complexes (data not shown). A 30-54\% enhancement of superoxide generation took place when increasing concentrations of histone (10-100 $\mu \mathrm{g} / \mathrm{ml}$ ) were added to LTA-sensitized PMNs in the presence of anti-LTA globulin. On the other hand no significant generation of $\mathrm{O}_{2}^{-}$was observed when LTA-sensitized PMNs were treated with histone alone in the absence of antiLTA. These results suggest that cationic agents might enhance the interaction of antibodies with antigens present on the surface of cells $(55,56)$.

Superoxide Generation by PMNs which Interacted with LTA-Anti-LTATreated Target Cells. Since LTA might also bind to a variety of target cells $(1,6,14,17,19)$ it was of interest to examine the possibility that such sensi- 
tized cells might further interact with anti-LTA antibodies and with PMNs to generate oxygen radicals. Fibroblasts and epithelial cells were grown in monolayers. The cells were trypsinized, washed in HBSS-HEPES, and resuspended in the same buffer. The cells were then pretreated for 20 min at $37^{\circ} \mathrm{C}$ with LTA and, again, washed in buffer. In some experiments, the cells were simultaneously treated with LTA and with proteases and washed. Anti-LTA or nonimmune rabbit globulin were then added in the presence of PMNs. Superoxide generation was determined after a further incubation for $20 \mathrm{~min}$ at $37^{\circ} \mathrm{C}$. Table 2 shows that larger amounts of superoxide are generated by PMNs which had interacted with protease-treated target cells as compared with nontreated targets. These data indicate that LTA can be presented to neutrophils by nonneutrophilic cells in a manner that will activate superoxide generation in the former and in the presence of anti-LTA.

Combined Effect of LTA and Membrane-Active Ligands on $\mathrm{O}_{2}^{-}$Generation. Previous studies (56) have shown that PMNs which had been primed either with the chemotactic peptide formylated methionyl leucine phenylalanine (FMLP) or with poly-L-arginine generated large amounts of $\mathrm{O}_{2}^{-}$when challenged by lectins. Since lipopolysaccharide (LPS), like LTA, also binds to membranes of cells via its lipid moiety, it was of interest to examine the pos-

Table 2. Generation of Superoxide by PMNs that Interacted with Target Cells Presensitized with LTA-Anti-LTA Complexes

\begin{tabular}{|c|c|c|c|}
\hline \multirow{2}{*}{$\begin{array}{l}\text { Target cells } \\
\text { treated with }\end{array}$} & \multirow[b]{2}{*}{ Followed by } & \multicolumn{2}{|c|}{$\begin{array}{c}\mathrm{O}_{2}^{-} \text {Generation } \\
\text { (nmol) by PMNs acting on }\end{array}$} \\
\hline & & Fibroblasts & Kidney cells \\
\hline None & Anti-LTA + PMNs & 7.0 & 8.1 \\
\hline LTA & Anti-LTA + PMNs & 21.0 & 18.0 \\
\hline LTA & PMNs & 10.0 & 10.7 \\
\hline LTA + trypsin & Anti-LTA + PMNs & 25.0 & 24.4 \\
\hline LTA + pronase & Anti-LTA + PMNs & 23.3 & 23.9 \\
\hline LTA & Rabbit Ig + PMNs & 6.5 & 7.0 \\
\hline None & PMNs & 6.8 & 6.8 \\
\hline
\end{tabular}

${ }^{a}$ Fibroblasts $\left(4 \times 10^{6} / \mathrm{ml}\right)$ or kidney cells $\left(4 \times 10^{6} / \mathrm{ml}\right)$ suspended in HBSS were treated for 15 min at $37^{\circ} \mathrm{C}$ either with buffer and trypsin $(10 \mu \mathrm{g} / \mathrm{ml})$, or with pronase $(10 \mu \mathrm{g} / \mathrm{ml})$ in the presence of LTA $(50 \mu \mathrm{g} / \mathrm{ml})$. The cells were washed in HBSS, resuspended in HBSS, and either anti-LTA globulin $(250 \mu \mathrm{g}$ protein $/ \mathrm{ml})$ or nonspecific rabbit globulin $(250 \mu \mathrm{g}$ protein $/ \mathrm{ml})$ was added. PMNs $\left(3.75 \times 10^{6} / \mathrm{ml}\right)$ were then mixed with the target cells in the presence of cytochrome $c(80 \mu \mathrm{M})$ and cytochalasin $\mathrm{B}(2.5 \mu \mathrm{g} / \mathrm{ml})$. The reaction mixtures were vortexed vigorously and further incubated for $10 \mathrm{~min}$ at $37^{\circ} \mathrm{C}$. Note that PMNs generate $\mathrm{O}_{2}^{-}$following interaction with LTA-sensitized targe cells, that protease treatment enhances $\mathrm{O}_{2}^{-}$generation, and that nonspecific rabbit globulin fails to trigger radical generation. 
sible collaboration among LPS, LTA, and other membrane-active ligands in $\mathrm{O}_{2}^{-}$generation. The ligands chosen to study synergism with LTA were: LPS, phytohemagglutinin (PHA), concanavalin A (Con A), the chemotactic peptide FMLP, the polyanion polyanethole sulfonate, and the polycations poly-L-arginine, poly-L-histidine, and histone. Except for polyhistidine all of the ligands employed singly induced the generation of relatively small amounts of superoxide (56). PMNs $\left(2 \times 10^{6} / \mathrm{ml}\right)$ were preincubated for $15 \mathrm{~min}$ at $37^{\circ} \mathrm{C}$ with LTA $(20 \mu \mathrm{g} / \mathrm{ml})$. The various ligands were then added in the presence of cytochrome $c$, and the reaction mixtures were further incubated for $10 \mathrm{~min}$ at $37^{\circ} \mathrm{C}$. Preincubation of PMNs with LTA depressed $\mathrm{O}_{2}^{-}$generation following the addition of polyanethole sulfonate by approximately $35 \%$. LTA by itself did not induce any $\mathrm{O}_{2}^{-}$generation above the levels generated by the PMNs. Similar suppression of $\mathrm{O}_{2}^{-}$generation took place when small amounts of polyhistidine were employed to stimulate LTA-sensitized PMNs. None of the other ligands employed triggered any enhanced generation of superoxide when added to LTAsensitized PMNs. The data suggest that, unlike LPS, LTA could not prime PMNs for enhanced generation of $\mathrm{O}_{2}^{-}$after addition of another ligand.

Release of Lysosomal Enzyme by LTA-Anti-LTA Complexes. Human PMNs $\left(5 \times 10^{6} / \mathrm{ml}\right)$ in HBSS containing $2.5 \mu \mathrm{g} / \mathrm{ml}$ of cytochalasin B were incubated for $30 \mathrm{~min}$ at $37^{\circ} \mathrm{C}$ with: (1) LTA $(30 \mu \mathrm{g} / \mathrm{ml})$-anti-LTA $(100 \mu \mathrm{g}$ protein/ml) complexes; (2) group A streptococci preopsonized with rabbit antistreptococcal globulin containing agglutinating antibodies to streptococci and supplemented with $10 \%$ fresh human serum as a source of complement; (3) group A streptococci $\left(10^{8} / \mathrm{ml}\right)$ mixed with histone $(100 \mu \mathrm{g} / \mathrm{ml})$. The reaction mixtures were then centrifuged $200 \mathrm{~g}$ for $10 \mathrm{~min}$, and the supernatant fluids were assayed for content of acid phosphatase (PHOSPH), $\beta$-glucuronidase (GLUC), $\mathrm{N}$-acetylglucosaminidease (NAGA), mannosidase (MANN), and lysozyme (LYZ). In parallel, PMNs sensitized with LTA and then treated with anti-LTA globulin were also tested for their capacity to generate $\mathrm{O}_{2}^{-}$. Supernatant fluids from PMNs subjected to five cycles of freezing and thawing were considered to contain the bulk of lysosomal enzymes. Figure 8 shows that LTA-anti-LTA complexes triggered the release of lysosomal enzymes. However, the degree of release of the five enzymes measured was lower than that induced by the opsonized particles. Since all ligands employed induced the generation of similar amounts of superoxide, the stimulation for enzyme release is not necessarily parallel to the stimulation needed to activate the NADPH oxidase in the PMN membranes.

Effect of Drugs on $\mathrm{O}_{2}^{-}$Generated by LTA-Anti-LTA Complexes. A variety of nonsteroidal and steroidal antiinflammatory drugs strongly inhibit oxygen radical generation by PMNs activated by both soluble and particulate ligands (59-62). Calmodulin inhibitors (63) and agents which interact with membrane 


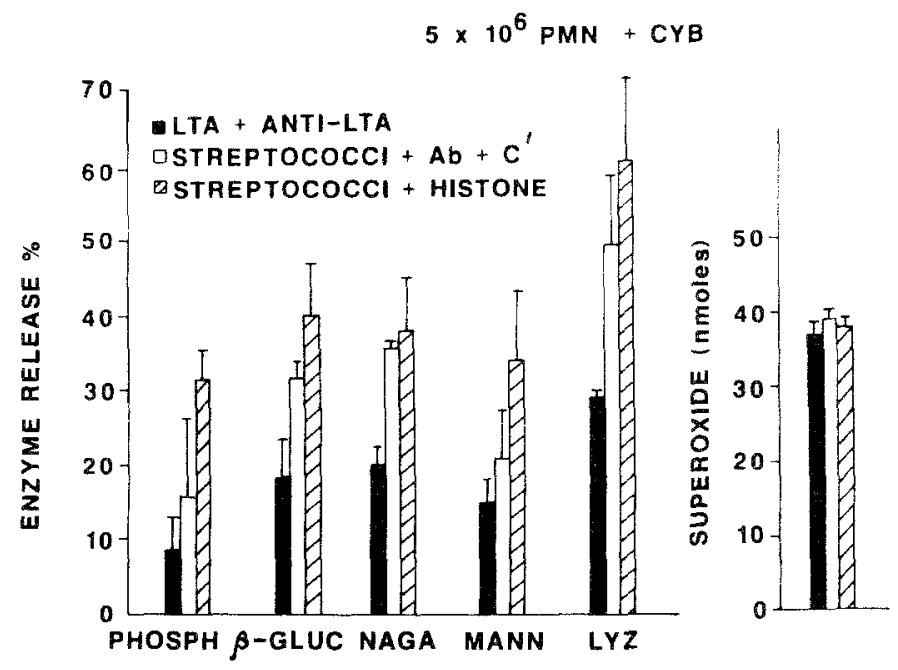

Fig. 8. Release of lysosomal enzymes and generation of superoxide by PMNs treated by various agonists. PMNs $\left(5 \times 10^{6} / \mathrm{ml}\right)$ were treated for $30 \mathrm{~min}$ at $37^{\circ} \mathrm{C}$ with LTA-anti-LTA complexes, streptococci opsonized with anti-streptococci Ig $+10 \%$ fresh human senum as a source of complement, and streptococci mixed with histone $(100 \mu \mathrm{g} / \mathrm{ml})$. CYB $(2.5 \mathrm{~g} / \mathrm{ml})$ was added to all reaction mixtures. The release of acid phosphatase (PHOSPH), $\beta$-glucoronidase ( $\beta$-GLUC), $N$ acetylglucosaminidase (NAGA), mannosidase (MANN), and lysozyme (LYZ) was determined in the supernates. In parallel, $3 \times 10^{6} \mathrm{PMNs} / \mathrm{ml}$ were stimulated by the same ligands, and the amounts of $\mathrm{O}_{2}^{-}$generated after $15 \mathrm{~min}$ of incubation at $37^{\circ} \mathrm{C}$ was also determined. The data represent the means and standard deviations of five experiments performed with PMNs from five different blood donors.

proteins (53) were also found to be strong inhibitors of oxygen radical generation. Since LTA-anti-LTA complexes interact with PMN membranes and since the $\mathrm{O}_{2}^{-}$-generating system of PMNs is associated with the cell surface (64), it was of interest to test the effects of a variety of drugs on the generation of superoxide by the LTA-anti-LTA system. The various drugs were dissolved in DMSO at $10 \mathrm{mg} / \mathrm{ml}$ and further diluted in saline to the appropriate concentrations. PMNs were preincubated for $10 \mathrm{~min}$ at $37^{\circ} \mathrm{C}$ with the drugs, followed by the addition of anti-LTA globulin, CYB, and cytochrome $c$. Figure 9 shows that strong inhibition of $\mathrm{O}_{2}^{-}$generation took place with NDGA, phenylbutazone, TFP, and DASA. On the other hand, even at millimolar concentrations, neither indomethacin nor ibuprofen had any significant inhibitory effects on superoxide generation by the LTA system. These data are in line with other findings which suggest that $\mathrm{O}_{2}^{-}$generation by LTA-anti-LTA complexes requires an intact lipoxygenase pathway. 


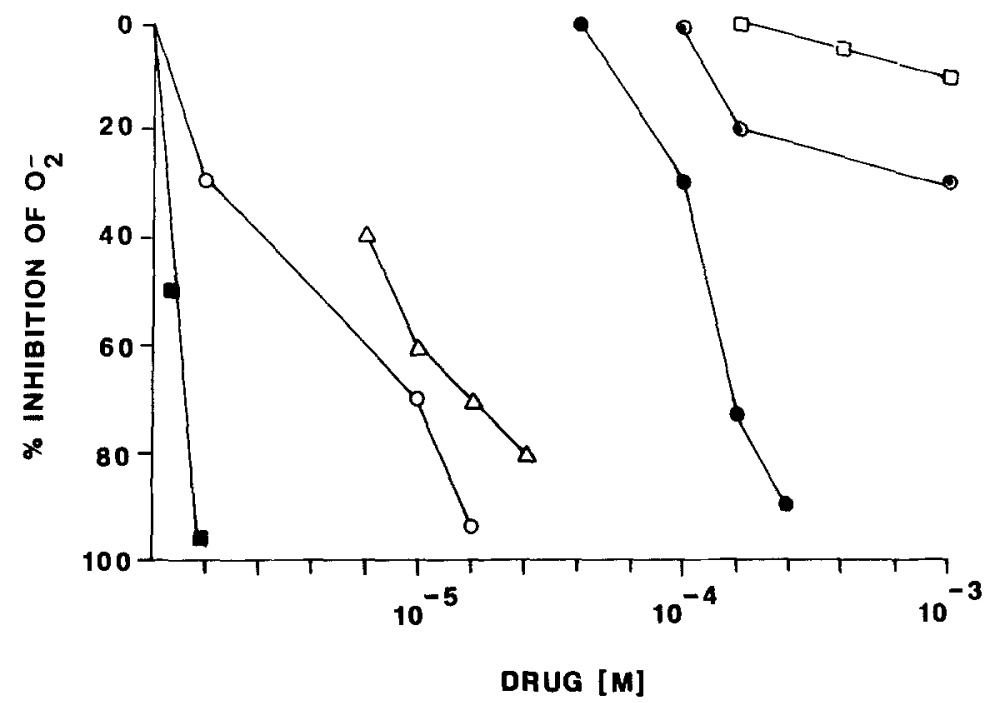

Fig. 9. Effect of drugs on $\mathrm{O}_{2}^{-}$generation inducated by LTA-anti-LTA complexes. $5 \times 10^{6} / \mu \mathrm{g}$ LTA-presensitized PMNs $\left(5 \times 10^{6} / \mathrm{ml}\right.$ ) (see Figure 6) were preincubated for $10 \mathrm{~min}$ at $37^{\circ} \mathrm{C}$ with increasing amounts of NDGA ( $(\triangle-\triangle)$, DASA, $(\bullet-\bullet)$, indomethacin $(\square-\square)$, and ibuprofen $(\odot-\odot)$ ). AntiLTA Ig $(250 \mu \mathrm{g}$ protein $/ \mathrm{ml})$, CYB $(2.5 \mu \mathrm{g} / \mathrm{ml})$, and cytochrome $c(80 \mu \mathrm{M})$ were then added, and the reaction mixtures were incubated for $15 \mathrm{~min}$ at $37^{\circ} \mathrm{C}$. Note the strong inhibition, at micromolar concentration, of $\mathrm{O}_{2}^{-}$generation by NDGA, TFP, and phenylbutazone, and the ineffective inhibition by millimolar concentrations of indomethacin and ibuprofen.

\section{DISCUSSION}

Lipoteichoic acid (LTA) is an ampiphatic macromolecular substance that interacts via its lipid moiety with membranes of mammalian cells $(2,4,6-9)$. Such "sensitized" cells undergo agglutination and lysis following the addition of anti-LTA antibodies and complement $(4,5,7-9,19)$. Since the putative binding sites for LTA in mammalian cells might be associated with phospholipids and cholesterol esters (19), it was expected the LTA might induce a transmembrane signal in PMNs leading to the activation of the NADPH oxidase in the membrane and generation of oxygen radicals. Our findings that no significant generation of such radicals took place when PMNs had been treated with large amounts of LTA alone suggests that not every agent which binds to PMN membranes elicits a respiratory burst. Thus, LTA differs from other membraneperturbing agents, e.g., lectins (65), FMLP peptides $(66,67)$, saponin (68), digitonin (68), lysolecithin (69), cationic poly-amino acids $(49,52,55,56)$, 
lipopolysaccharides (58), etc., which bind to PMN and macrophage membranes and elicit a respiratory burst. To secure the generation of $\mathrm{O}_{2}^{-}$and chemiluminescence (CL), LTA-sensitized PMNs must be further treated with anti-LTA antibodies (Figures 1-7). Such cells agglutinated and rapidly generated superoxide. Significant activity was observed less than 1 min following the addition of antibodies (Figure 2). Very rapid oxygen radical generation was also monitored by chemiluminescence (Figure 3 ).

The mechanism by which LTA-anti-LTA complexes trigger a respiratory burst is still not fully understood. This system should, however, be compared with classical immune complexes such as BSA-anti-BSA, which have been shown to trigger the generation of oxygen radicals by neutrophils (46). Figure $10 \mathrm{~A}$ is a schematic representation of the interrelationships that might occur when PMNs interact with haptens, like LTA, and with anti-LTA antibodies. It may be expected that LTA binds to the PMN membrane, presumably to phospho-

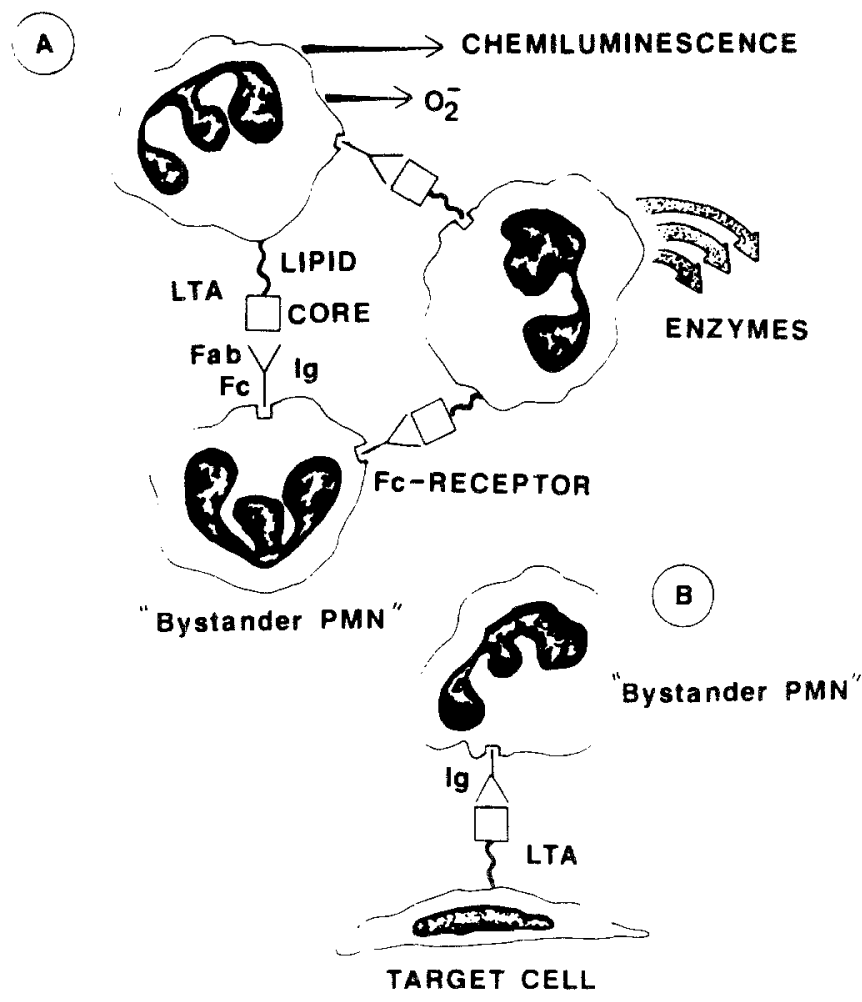

Fig. 10. Schematic representation of $(A)$ the interaction of LTA-sensitized PMNs with anti-LTA antibodies and with bystander nonsensitized PMNs and (B) the interaction of LTA-sensitized target cells (fibroblasts, endothelial cells) with PMNs. 
lipids, via its lipid moiety (19). This is followed by the interaction of the Fab portion of the immunoglobulin with the LTA core already present on the PMN surface. Since the Fc portion of the immunoglobulin is unengaged, it might further interact either with the $\mathrm{Fc}$ receptors of neighboring LTA-sensitized cells or with bystander nonsensitized PMNs. The results of these interactions include cell agglutination and membrane perturbation leading to the generation of oxygen radicals (Figures 1-7) and to the release of lysosomal enzymes (Figure 8). On the other hand, much less $\mathrm{O}_{2}^{-}$might be generated when PMNs interact with LTA-sensitized target cells, like fibroblasts, which do not possess an NADPH oxidase and which therefore cannot mount a respiratory burst (Table 2, Figure 10B). It also appears that the production of $\mathrm{O}_{2}^{-}$by the LTA-anti-LTA system might start much earlier than that induced either by LTA bound to the target cells or when PMNs are challenged directly with an immune complex (Figure 2).

To further prove that bystander PMNs interact with LTA-sensitized PMNs via the $F c$ fraction of the immunoglobulin, $F\left(a b^{\prime}\right)_{2}$ fragments of the anti-LTA antibodies should be prepared. Since, however, the bulk of anti-LTA antibodies have been found to be associated with the IgM fraction (20), this task is more complicated and further studies along these lines are warranted.

Since the binding of LTA and PMNs markedly depressed $\mathrm{O}_{2}^{-}$generation by other immune complexes (Figure 4), it appears that some of the $\mathrm{Fc}$ receptors of PMNs might be blocked, nonspecifically, by LTA following its interaction with phospholipid components of the membrane. These findings might have relevance to the modulation of cell destruction under in vivo conditions (see below).

The findings that much larger amounts of $\mathrm{O}_{2}^{-}$are generated when PMNs are simultaneously challenged with LTA and with BSA complexes as compared with the amounts generated with each complex alone is also of interest. It appears that although LTA interfered with the binding of BSA complexes to PMNs, the two immune complex systems might still induce an augmented respiratory burst, which under in vivo conditions might mimic an infectious site rich in multiple cell-membrane-injuring agents.

The findings that cationic agents further enhance $\mathrm{O}_{2}^{-}$generation induced by LTA-anti-LTA complexes is in line with previous findings (54) on the enhancement of the reverse Arthus reaction in the skin of rats injected with cationized antibodies and challenged intravenously with radiolabeled antigens. It appears that the cationic charge upon antibodies might facilitate their interactions with the antigens. Furthermore, cationized antibodies or antigens might persist in the tissues for longer periods $(54,55)$.

The finding that CYB markedly enhanced $\mathrm{O}_{2}^{-}$generation induced by LTAanti-LTA complexes (Figure 6) is in line with assumption that CYB and other cytoskeleton-modifying agents might lead to the expansion of the cell mem- 
brane allowing a better interaction of antibodies with membrane agents like LTA. CYB has been shown to augment the generation of $\mathrm{O}_{2}^{-}$and the secretion of lysosomal enzymes from neutrophils $(49,52,56,71,72)$.

The findings that proteolytic enzymes further enhanced the generation of superoxide following stimulation with LTA-anti-LTA complexes is similar to our previous observation on the enhancement of binding of LTA to RBC (19). The abundance of proteases in inflammatory and infectious sites might therefore be responsible for enhancing the generation of toxic oxygen radicals and tissue damage.

The failure to enhance the generation of $\mathrm{O}_{2}^{-}$by adding fresh serum rich in complement is in line with the observations (73) that PMNs failed either to phagocytize or to generate toxic oxygen radicals when challenged with $\mathrm{C} 3 \mathrm{~b}$ coated particles. These findings suggest that although the $\mathrm{Fc}$ portion of the immunoglobulin might be unengaged, complement might not be activated under the conditions of our experiments. On the other hand, the findings that LTAanti-LTA complexes not bound to cells readily activate complement $(26,27)$ and that complement activation resulted in the death of a variety of LTA-sensitized target cells (fibroblasts, tumor cells, and RBCs) $(19,22,23)$ indicate that further studies to elucidate this controversial finding should be performed.

Like many other types of immune complexes, LTA-anti-LTA triggers the release of lysosomal enzymes from PMNs (Figure 8). However, the finding that the levels of the five enzymes measured which had been release by the LTA system are much lower than those induced by opsonized particles suggests that different agonists vary in their capacity to induce the type of membrane perturbation leading to degranulation. It is of interest that all three stimulators employed in the enzyme release assays triggered the generation of comparable amounts of superoxide, suggesting that the signals which elicit a respiratory burst and enzyme release might be different.

The inhibition of $\mathrm{O}_{2}^{-}$generation indicated by the LTA system by putative inhibitors of the lipoxygenase pathway of arachidonic acid metabolism, by calmodulin antagonists, by phenylbutazone, as well as by DASA, an agent shown to inhibit surface membrane proteins (Figure 8), suggests that LTA complexes might enhance conversion of arachidonic acid to certain intermediates associated with the NADPH oxidase. Intracellular calcium is needed for such a reaction, and inhibition of a still unknown surface protein participates in the complex metabolic pathway leading to the generation of oxygen radicals.

Finally, the possible role played by LTA-anti-LTA complexes in the initiation of tissue damage in vivo should be briefly discussed. LTA is synthesized by all Gram-positive bacteria. This ampiphatic substance might facilitate the adherence of bacterial cells to cell surfaces which then facilitates the invasion of bacteria (14-17). Since LTA might be released from bacterial cells either by polycationic agents (10) or following bacteriolysis induced by the activation of 
their own autolytic enzymes $(44,48)$, it is suggested that free LTA might be present in infectious inflammatory sites induced by Gram-positive bacteria, e.g., subacute bacterial endocarditis. The facilitation of membrane attachment of LTA by proteolytic enzymes might further enhance cytolytic reactions mediated either by PMNs (antibody-dependent cellular cytotoxicity) (38) or by complementdependent cellular cytotoxicity (19). Activation of complement by LTA-antiLTA systems might release anaphylatoxin and other mediators of inflammation that might augment the inflammatory response.

The generation of cellular damage (chromium release assays) (38) and of oxygen radicals when target cells are treated with LTA-anti-LTA and PMNs (Table 2) also suggests that the LTA system might function to further enhance cellular cytotoxicity by releasing oxygen radicals and proteases. In preliminary experiments (Ginsburg, Varani, and Ward, in press), we found that monolayers of fibroblasts, endothelial cells, or fibrosarcoma cells that had been sensitized with LTA and treated with anti-LTA globulin and with human neutrophils sloughed off the plastic surfaces but were not killed. The incorporation in the reaction mixture of sodium azide or aminotriazole (inhibitors of catalase and myeloperoxidase) enhanced cell killing, suggesting that these inhibitors prevented the destruction of hydrogen peroxide produced by the PMNs. Since the sloughing off of the monolayers but not killing was totally prevented by proteinase inhibitors, we assumed that proteolytic enzymes released from the activated PMNs were responsible for the disruption of the architecture of the cell monolayers. It appears, therefore, that LTA-anti-LTA complexes might prove cytolytic and might also facilitate the dislodgement of cells from tissues (74) and perhaps also the dissemination of infected cells and tumor cells leading to enhanced metastasis.

\section{REFERENCES}

1. WiCkEN, A. J., and K. W. Knox. Lipoteichoic acids: A new class of bacterial antigen. Science 187:1161-1167.

2. Shockman, G. D., and A. J. Wicken. 1981. Chemistry and Biological Activities of Bacterial Surface Amphiphiles. Academic Press, New York.

3. HuFF, E. 1981. Lipoteichoic acid, a major amphiphile of Gram-positive bacteria that is not readily extractable. J. Bacteriol. 149:399-402.

4. HARRIS, T. N., and S. HARRIS. 1953. Agglutination by human sera of erythrocytes incubated with streptococcal culture supernates. J. Bacteriol. 66:159-165.

5. NeTER, E. 1956. Bacterial hemagglutinization and hemolysis. Bacteriol. Rev. 20:166-188.

6. StEWART, F. S., and W. T. MARTin. 1962. Absorption of streptococcal red cell sensitizing antigen to various tissues. J. Pathol. Bacteriol. 84:251-253.

7. JACKSON, R. W., and M. Moskowitz. 1966. Nature of red cell sensitizing substance from streptococci. J. Bacteriol. 91:2205-2209. 
8. Moskowrrz, M. 1966. Separation and properties of a red-cell-sensitizing substance from streptococci. J. Bacteriol. 91:2200-2204.

9. Neeman, N., and I. GinsBurg. 1972. Red cell sensitizing antigen of group streptococci. I. Biological and chemical properties. Isr. J. Med. 8:1799-1806.

10. SEla, M. N., M. LaHVA, and I. GinSBURG. 1977. Effect of leukocyte hydrolase on bacteria. IX. The release of lipoteichoic acid from group A streptococci and from Streptococcus mutans by leukocyte extracts by lysozyme: Relation to tissue damage in inflammatory sites. Infiammation 2:151-164.

11. Horne, D., and A. Tomasz. 1979. Release of lipoteichoic acid from Streptococcus sanguis. Stimulation of release during penicillin treatment. J. Bacteriol. 137:1180-1184.

12. Nealon, M. J., E. H. Beachey, H. S. Courtney, and A. Simpson. 1986. Release of fibronectin-lipoteichoic acid complexes from group a streptococci with penicillin. Infect. Immun. 51:529-535.

13. KNoX, K. W., and A. J. WICKEN. 1975. Immunological properties of teichoic acids. Bacteriol. Rev. 37:215-257.

14. Ofek, I., E. H. Beachey, W. Jefferson, and G. L. CAmpbell. 1975. Cell membrane binding properties of group A streptococcal lipoteichoic acid. J. Exp. Med, 141:990-1003.

15. BEACHEY, E. H., and I. OFEK. 1976. Epithelial cell binding on group A streptococcal by lipoteichoic acid on fimbriae of denuded M protein. J. Exp. Med. 143:759-771.

16. BeACheY, W. H., T. M. ChIANG, I. OFEK, and A. H. KANG. 1977. Interaction of lipoteichoic acid with human platelets. Infect. Immun. 16:649-654.

17. Courtney, H., I. Ofek, A. Simpson, and E. H. Beachey. 1981. Characterization of lipoteichoic acid binding to polymorphonuclear leukocytes of human blood. Infect. Immun. 32:625631 .

18. Courtney, H. S., A. W. Simpson, and E. H. Beachey. 1986. Relationship of critical micelle concentrations of bacterial lipoteichoic acid to biological activities. Infect. Immun. 51:414418.

19. Dishon, T., R. Finkel, Z. Marcus, and I. Ginsburg. 1967. Cell sensitizing products of streptococi. Immunology 13:555-564.

20. NeEman, N., and I. Ginsburg. 1971. Red cell sensitizing agent of group A streptococci. II. Immunological and immunopathological properties. Isr. J. Med. Sci. 8:1807-1816.

21. Ferne, M., S. Bergner-Rabinowitz, and I. Ginsburg. 1976. The effect of leukocyte hydrolases on bacteria. IV. The role played by leukocyte extracts in the sensitization of RBC by lipopolysaccharides and the cell-sentitizing factor of group A streptococci. Inflammation 1:247260.

22. Hummel, S. D., and J. A. WInKELSTEIN. 1986. Bacterial lipoteichoic acid sensitizes host cells for destruction by autologous complement. $J$. Clin. Invest. 77:1533-1538.

23. B. D. Weinkeb, G. D. Shockman, S. E. Beachey, A. J. Swift, and J. A. Winkelstein. 1986. The ability of sensitized host cells for destruction by autologous complement is a general property of lipoteichoic acid. Infect. Immun. 54:797-799.

24. Simpson, W. A., J. B. Dale, and E. H. Beachey. 1982. Cytotoxicity of the glycolipid region of stretococcal lipoteichoic acid for cultures of human heart cells. J. Lab. Clin. Med. 99:118126.

25. LEON, O., and C. PANOS. 1983. Cytotoxicity and inhibition of normal collagen synthesis in mouse fibroblasts by lipoteichoic acid of Streptococcus pyogenes type 12. Infect. Immun. 40:758-794.

26. LoOS, M., F. ClAS, and W. FisChER. 1986. Interaction of purified lipoteichoic acid with the classical complement pathway. Infect. Immun. 53:595-599.

27. Winkelstein, J. A., and A. Tomasz. 1978. Activation of the alternative complement pathway for pneumococcal cell wall teichoic acid. J. Immunol. 120:174-178. 
28. Hadrop, P. J., R. L. Grady, K. W. Knox, and A. J. Wicken. 1980. Stimulation of lysosomal enzyme release macrophages by lipoteichoic acid. J. Periodont. Res. 15:492-501.

29. Ginsburg, I., and P. G. QUIE. 1980. Modulation of human polymorphonuclear chemotaxis by leukocyte extracts, bacterial products, inflammatory exudates and polyelectrolytes. Inflammation 4:310-311.

30. RaynoR, R. H., D. F. SCOTt, and G. K. Best. 1981. Lipoteichoic acid inhibition of phagocytosis of Staphylococcus aureus by human polymorphonuclear leukocytes. Clin. Immunol. Immunopathol. 19:181-189.

31. Sela, M. N., I. Ginsburg, T. Dishon, Z. Duchan, and A. A. Garfunkel. 1982. Modulation of human lymphocyte transformation by bacterial products and leukocyte lysates. Inflammation 6:31-38.

32. AASJORD, P., H. NYLAND, and R. MARTE. 1986. The mitogenic properties of lipoteichoic acid from Staphylococcus aureus. Acta Pathol. Microbiol. Immunol. Scand. Sect. C 94:91-96.

33. Miller, G. A., and R. W. JACKSON. 1973. Effect of a streptococcus pyogen teichoic acid on the immune response of mice. J. Immunol. 110:148-156.

34. Hausman, E., O. Luderitz, K. W. Knox, and N. W. Weinfeld. 1975. Structural requirements for bone resorption by endotoxin and lipoteichoic acid. J. Dent. Res. 54:94-99.

35. BAb, I., M. N. Sela, I. Ginsburg, and T. Dishon, 1979. Inflammatory lesion and bone resorption induced in rat periodontium by lipoteichoic acid. Inflammation 3:345-358.

36. AASJORD, P., H. NYLAND, and S. MORK. 1980. Encephalitis in rabbits by lipoteichoic acid. Acta Pathol. Microbiol. Scand. Sect. C 88:287-291.

37. FIEDEL, L. A., and R. W. JACKSON. 1979. Nephropathy in the rabbit associated with immunization to group A streptococcal lipoteichoic acid. Med. Microbiol. Immunol. 167:251-260.

38. Lopatin, D., and R. E. Kessler. 1985. Pretreatment with lipoteichoic acid sensitizes target cells to antibody-dependent cellular cytotoxicity in the presence of anti-lipoteichoic antibodies. Infect. Immun. 48:638-643.

39. Yamammoto, A., H. Usami, M. Nagamuta, Y. Sugawara, S. Hamada, T. Yamamoto, K. Kato, S. Kokeguchi, and S. Kotami. 1985. The use of lipoteichoic acid (LTA) from streptococcus pyogen to induce a serum factor causing tumor necrosis. Br. J. Cancer 51:739-742.

40. LeON, O., and C. PANOS. 1985. Effect of streptococcal lipoteichoic acid on prolyl hydroxylase activity as related to collagen formation in mouse fibroblasts. Infect. Immun. 50:641-646.

41. Holrue, J. V., and A. Tomasz. 1975. Lipoteichoic acid: A specific inhibitor of autolysin activity in pneumococci. Proc. Natl. Acad. Sci. U.S.A. 72:1690-1691.

42. Cleveland, R. F., A. J. Wicken, L. Daneo-Moore, and G. D. Shockman, 1976. Inhibition of wall autolysis in Streptococcus faecalis by lipoteichoic acid. J. Bacteriol. 126:192-197.

43. Sela, M. N., I. Ofek, M. Lahav, and I. GinsBurg. 1978. The effect of leukocyte hydrolases on bacteria. XI. Lysis by leukocyte extracts and myeloperoxidase of Staphylococcus aureus mutant which is deficient in teichoic acid and the initiation of bacteriolysis by lipoteichoic acid. Proc. Soc. Exp. Biol. Med. 159:126-130.

44. Tomasz, A., and S. WAKs. 1975. Mechanism of action of penicillin: Triggering of pneumococcal autolytic enzyme by inhibitors of cell-wall synthesis. Proc. Natl. Acad. Sci. U.S.A. 72:4162-4166.

45. Tomasz, A. 1979. The mechanisms of irreversible anti-microbial effect of penicillin: How the beta lactam antibiotics kill and lyse bacteria. Annu. Rev. Microbiol. 33:113-137.

46. WEISS, S. J., and P. A. WARD. 1982. Immune complex induced generation of oxygen metabolites of human neutrophils. J. Immunol. 129:309-313.

47. FisCHER, W., H. V. KACH, and P. HAAS. 1983. Improved preparation of lipoteichoic acids. Eur. J. Biochem. 154(3):1115-1116.

48. GinsBurg, I. 1972. Mechanisms of cell and tissue injury induced by group A streptococci: Relation to poststreptococcal sequelae. J. Infect. Dis. 120:294-315. 
49. Ginsburg, I., R. Borinski, D. Malamud, F. Struckmeire, and V. Klimetzek. 1985. Chemiluminescence and superoxide generation by leukocytes stimulated by polyelectrolyte-opsonized polyhistidine, cytochalasins and inflammatory exudates as modulators of oxyen burst. Inflammation 9:245-271.

50. Babior, B., J. T. Curnutte, and B. McMurrich. 1976. The particulate superoxide forming system from human neutrophils: Properties of the system and further evidence supporting its participation in the respiratory burst. J. Clin. Invest. 58:989-996.

51. Thurman, R. G., H. G. Leyland, and R. Scholz. 1972. Hepatic microsomal ethanol oxidation, hydrogen peroxide formation and the role of catalase. Eur. J. Biochem. 25:420-430.

52. Ginsburg, I., R. Borinski, M. Sadovnic, Y. Eilam, and K. Rainsford. 1987. Poly-L-histidine: A potent stimulator of superoxide generation in human blood leukocytes. Inflammation 11:253-277.

53. MCPhail, L. C., P. Henson, and R. B. Johnston. 1981. Respiratory burst enzyme in human neutrophil: Evidence for multiple mechanisms of activation. $J$. Clin Invest. 67:710-716.

54. Warren, J. S., P. A. WARd, K. J. Johnson, and I. Ginsburg. 1987. Modulation of acute immune complex-mediated tissue injury by the presence of polyionic substances. Am. J. Pathol. 128:67-77.

55. GinSBURG, I. 1987. Cationic polyelectrolytes: A new look at their possible roles as opsonins, as stimulators of the respiratory burst in leukocytes, in bacteriolysis and as modulators of immune complex disease. Inflammation 11:489-515.

56. Ginsburg, I., R. Borinski, M. Lahav, Y. Matzner, I. Elifasson, P. Christensen, and D. MALAMUD. 1984. Poly-L-arginine and $\mathrm{N}$-formylated chemotactic peptide act synergistically with lectin and calcium inonophore to induce intense chemiluminescence and superoxide production in human blood leukocytes: Modulation by metabolic inhibitors of sugars and polyelectrolytes. Inflammation 8:1-26.

57. Henricks, P. A., M. Van der Tol, R. M. W. M. Thyssen, B. S. VAn Asbeck, and J. VerHOEF. 1983. Escherichia coli lipopolysacchride diminish and enhance cell function of human polymorphonuclear leukocytes. Infect. Immun. 4:294-301.

58. Kapp, A., M. FreudenberG, and C. Gallanos. 1987. Induction of human granulocyte chemiluminesence by bacterial lipopolysaccharides. Infect. Immun. 55:758-761.

59. Abramson, S., H. Edelson, H. Kaplan, W. Given, and G. Weissmann. 1984. The inactivation of the polymorphonuclear leukocyte by nonsteroidal antiinflammatory drugs. Inflammation 8:S103-S108.

60. Fantone, J. C., W. A. Marasco, L. J. Elgas, and P. Ward. 1984. Stimulus specificity of prostaglandin inhibition of rabbit polymorphonuclear leukocyte lysosomal enzyme release and superoxide anion production. Am. J. Pathol. 115:9-16.

61. WARD, P. A., M. C. SULAVIK, and K. J. JOHNSON. 1984. Rat neutrophil activation and effects of lipoxygenase and cyclooxygenase inhibitors. Am. J. Pathol. 116:223-233.

62. Sedgwick, J. B., M. L. Berube, and R. B. Zurier, 1985. Stimulus-dependent inhibition of superoxide generation by prostaglandins. Clin. Immunol. Immunopathol. 34:205-215.

63. COHEN, H. J., M. E. ChOVANIEC, and S. E. Ellis. 1980. Chloropromazin inhibition of granulocyte superoxide production. Blood 56:23-29.

64. Goldstein, I. M., M. Cerquerira, S. Lind, and H. Kaplan. 1977. Evidence that superoxide-generating system of human leukocytes is associated with the cell surface. J. Clin. Invest. 59:249-254.

65. RomeO, D., G. SABUCCHI, and F. Rossi. 1973. Reversible metabolic stimulation of polymorphonuclear leukocytes and macrophages by concanavalin. Nature 243:111.

66. HatCh, G., D. E. Gardner, and D. B. Menzel. 1978. Chemiluminescence of phagocytic cells caused by $N$-formyl-methionyl peptide. J. Exp. Med. 147:182-195.

67. BeCker, E. L., M. Sigman, and M. Oliver. 1979. Superoxide production induced in rabbit 
polymorphonuclear leukocytes by synthetic chemotactic peptide and A23187: The nature of receptor and the requirement of $\mathrm{Ca}^{++}$. Am. J. Pathol. 95:81-97.

68. Cohen, H. J., and M. E. ChovaniEc. 1978. Superoxide generation by digitonin stimulated guinea-pig granulocytes. A basis for continuous assay for monitoring superoxide production. J. Clin. Invest. 61:1081-1087.

69. GINSBURG, I., R. BORINSKI, and M. PABST. 1985. NADPH and "cocktails" containing polyarginine reactivate superoxide generation in leukocyte lysed by membrane-damaging agents. Inflammation 9:341-363.

70. WeISS, S. J., and P. WARD. 1982. Immune complex induced generation of oxygen metabolite by human neutrophils. J. Immunol. 129:309-313.

71. Malawista, S. E., J. B. L. Gee, and K. G. Bensch. 1971. Cytochalasin B reversibility inhibits phagocytosis: Functional, metabolic and structural effects in human blood leukocytes and rabbit alveolar macrophages. Yale J. Biol. Med. 44:286-300.

72. Elferink, J. G. R., and J. C. Riemersma. 1981. The effect of cytochalasin on polymorphonuclear leukocytes activated by chemotactic peptide. J. Reticuloendothelial Soc. 29:163-174.

73. Wright, S. D., and S. D. Silverstein. 1983. Receptors for C3b and C3bi promote phagocytosis but not the release of toxic oxygen from human phagocytes. J. Exp. Med. 158:20162023.

74. Ginsburg, I., S. E. G. Fligiel, R. G. Kunkel, and J. Varani. 1987. Phagocytosis of Candida albicans enhance malignant behavior of murine tumor cells. Science 238:1573-1575. 